\title{
Impact of Reading on the Biological Foundations of Language, Cognition, and Emotion
}

\author{
Radhakrishnan Sriganesh ${ }^{1}$ and R. Joseph Ponniah ${ }^{2}$ \\ ${ }^{1}$ Research Scholar, Department of Humanities and Social Sciences, National Institute of \\ Technology Tiruchirappalli, Tiruchirapalli - 620015 \\ ${ }^{2}$ Professor of English, Department of Humanities and Social Sciences, National Institute of \\ Technology Tiruchirappalli, Tiruchirappalli - 620015 \\ ORCID: oooo-0oo2-o618-6788. Email: joseph@nitt.edu
}

\begin{abstract}
The article explores the biology of reading and how reading influences the biological relationship among language, cognition, and emotion (LCE). Reading aids in the enhancement of LCE under the precondition that biological predispositions for reading ability and LCE, such as genetic makeup, epigenetic modifications and neuronal development are favourable. A conceptual model was developed to explain how reading incrementally enhances LCE. The model serves as a tool to understand the biological and pedagogical conditions through which reading helps in progressing through successive LCE levels. The article also proposes that this holistic perspective of reading, considering genetics, epigenetics, neuroscience, neuropsychology and pedagogy, paves way for targeted clinical and educational interventions for people with language learning difficulties/disability.
\end{abstract}

Keywords: biology of reading; epigenetics; synaptic plasticity; neurogenetics of reading

\section{Biology of Reading Ability}

Functional neural network of brain is associated with polymorphisms of a set of genes promoting inter-individual differences in functional connectivity of the brain (Richiardi et al., 2015). Therefore, the functional neural network corresponding to reading ability is also characterized by neurogenetic dispositions which cause inter-individual differences among readers. Moreover, since reading ability involves innate abilities such as language and object recognition, its genetic association is expected to be high, which is evident from the research on reading disability (Olson, 2006; Swagerman et al., 2017). Genome-wide association studies (GWAS) on reading ability provide insights into the genes responsible for reading. These studies associate several candidate genes for reading disability (dyslexia). $D Y X_{1} C_{1}$ (Taipale et al., 2003), $R O B O_{1}$ (Hannula-Jouppi et al., 2005; Tran et al., 2014), DCDC2 (Meng et al., 2005) and KIAAo319 (Cope et al., 2005), MRPL19/C2ORF3 (Scerri et al., 2012) are some examples of reading candidate genes identified through GWAS on dyslexia. So far, more than 20 candidate genes for reading disability (for reading ability too as a corollary) have been identified by the Human Gene Nomenclature Committee (Raskind et al., 2013). Secondly, reading disability, also known as dyslexia, runs in families suggesting that reading development is genetic. Thirdly, visual word form area (VWFA), a key reading-specific subskill is universal among

\footnotetext{
(c) AesthetixMS 2020. This Open Access article is published under a Creative Commons Attribution Non-Commercial 4.0 International License (http://creativecommons.org/licenses/by-nc/4.o/), which permits non-commercial re-use, distribution, and reproduction in any medium, provided the original work is properly cited. For citation use the DOI. For commercial re-use, please contact editor@rupkatha.com.
} 
human beings (Dehaene, 2010), suggesting that genetic makeup is also a reason why reading ability must be viewed in terms of biology apart from just viewing it as a skill developed in a classroom.

\section{Biology of Environmental Reading Acquisition}

Reading, as discussed above, is a complex blend of several innate cognitive subskills, especially those involving object recognition, phonemic and phonological awareness, word-forming, and meaning associations (Olson, 2006). These subskills are acquired through the formation of specialized networks of neurons corresponding to each subskill, forming different, interacting areas in the brain corresponding to each subskill. Formation of such networks is possible due to a property of brain known as synaptic plasticity, an ability of the brain to alter its biochemical and morphological character in response to the input received from the environment (Morris, 2004). Synaptic plasticity is a vital property required for actuating cognitive processes related to reading. Reading attainment requires an efficient interconnection of brain areas corresponding to reading and language subskills and the effectiveness of synaptic plasticity in the brain is an important factor in reading achievement.

Initially, the environmental reading input provides visual stimuli to the brain, and this triggers the neurons in different brain areas corresponding to object recognition, language and other supporting cognitive subskills. These neurons emit/receive neurotransmitters which act as electrical signaling and regulators to connect (or disconnect) with other sets of neurons to form interconnected neuronal networks among different functional brain areas (Kraus et al., 2017) that facilitate reading. Thus, effective neurotransmission and synaptic plasticity are preconditions for successful reading attainment. Neurotransmitters are regulated by genes (Caspi et al., 2010) and DNA methylation (Kennedy et al., 2016). Studies have confirmed that synaptic plasticity, particularly those corresponding to learning and memory, are genetically endowed (Kennedy et al., 2016) and epigenetically regulated (Felling \& Song, 2015). Also, inter-individual differences in reading achievement are owed to genetic variants (such as single nucleotide polymorphisms (SNPs), copy number variants (CNVs), deletions, insertions, and duplications). For example, SNPs of reading associated genes, $C C D C_{13} 6 / F L N C$ and $R B F O X_{2}$ are found to be linked with reading scores of non-dyslexic children and with the restructuring of their neurons (Gialluisi et al., 2017). These facts show how epigenetic mechanisms and genetic predispositions play a major role in reading acquisition.

In addition to epigenetic mechanisms affecting reading ability, reading habit also affects gene expressions through epigentic mechanisms. Precisely, if the genes expressed for reading ability are favorable, the effects of environmental stimuli such as cognitive skills enhanced by comprehension, and the pleasure derived from reading will have a significant impact on neuronal cells through epigenetic mechanisms triggered by neurotransmitters (Cortés-Mendoza et al., 2013). Studies suggest that environmental stress can impact gene expressions through epigenetic mechanisms (McEwen, 2016; McEwen et al., 2012). If stress is epigenetically regulated, pleasure derived from reading also will be subject to epigenetic regulation of genes concerned. The epigenetically induced genetic markers could be the reason why the benefits of reading are prolonged, often throughout life.

In addition to reading being a biologically rendered ability that is learnt with the help of stimuli from the environment, reading is also closely associated with biological underpinnings of LCE. A closer analysis of biological interactions between reading and each component of LCE can ascertain the importance of reading in the development of LCE. To sum up, reading is influenced 
by (and influences) genetic, epigenetic, and neurobiological mechanisms corresponding to abilities of reading, language, cognition, and emotion. These mechanisms cause the differences in the efficiency of reading for each learner, leading to inter-individual differences in reading, a closer understanding of which is crucial in solving reading difficulties.

\section{Biological Relationships Between Reading and LCE}

This section elaborates the current knowledge in the biological relationship between reading and each of language, cognition and emotion.

\subsection{Reading and Language}

Though language is an ability predetermined by biological (genetic and epigenetic) mechanisms, language acquisition is not possible without the help of environmental language input. During the initial stages of mother tongue acquisition, listening is the primary mode of language input, which is then followed by reading. However, reading, in the form of both academic and pleasure reading, plays a dominant role in enhancing language acquisition, with language developing rapidly during the reading stage. Also, in a second language classroom setup, listening input is restricted to classroom environment and depends on the non-native teacher's limited proficiency in the language, whereas reading is a reliable mode of language input. Therefore, reading plays a dominating and deterministic role in second language acquisition also. Extensive reading engaged by second language learners is observed to have a lasting impact in terms of second language acquisition (Jennifer \& Ponniah, 2017; Lee et al., 2015). The more the reading is habituated, the better will be the language improvement (Cunningham \& Stanovich, 1998; Jennifer \& Ponniah, 2018). Gains in vocabulary and improvement in grammar through extensive reading habit are also reported widely in research (Ghanbari \& Marzban, 2014; Mol et al., 2009; Wasik et al., 2016).

Environmental reading acquisition shares most brain areas or neuronal networks with those of language acquisition except for skills specific to reading such as object recognition and decoding the orthographic symbols to phonological representations. The shared neural network gets strengthened in the process of reading, eventually benefitting both reading and language. For example, reading is found to strengthen the language-processing areas of the brain (Dehaene et al., 2015; Petersson et al., 2000).

As expected of all genetic abilities, language ability is associated with several genes and their variants, as evident from research on a wide variety of language disorders (Onnis et al., 2018, Rahul \& Ponniah, 2019, Sriganesh \& Ponniah, 2018). In addition, studies have pointed out that language and reading abilities are biologically associated even at a molecular level, which is understandable since reading is primarily a language-derived skill. Specifically, genes that are expressed for language ability have effects on reading (and vice versa). This is validated by genetic studies on language and reading. Genes such as $C C D C_{136 / F L N C}$ and $R B F O X_{2}$ were identified as candidate genes for both reading and language disabilities (Gialluisi et al., 2014). Also, CMIP, a candidate gene for specific language impairment (SLI), is found to be associated with the reading ability (Scerri et al., 2011). Thus, the biological relationship between reading and language is established at the molecular level itself. 


\subsection{Reading and Cognition}

Reading provides a key link between language and cognition. Language is acquired naturally with the help of environmental listening input, and the enrichment of language and higher-order cognition happens through continued habit of reading. Habitual reading enhances higher-order cognition such as comprehension, general knowledge (Clark \& Rumbold, 2006), critical thinking and analysis, problem-solving, decision making, and theory of mind (Black \& Barnes, 2015; Kidd \& Castano, 2013) which constitutes the ability to predict and infer our own and others' beliefs, desires and intentions (Malle, 2005). These cognitive abilities developed through reading assist in building a complex and creative thought; and the language developed through reading helps in expressing such thoughts effectively.

Cognitive mechanisms in the brain are regulated by neurotransmitters, especially dopamine (Elvevåg \& Weinberger, 2009), which in turn is regulated by epigenetic processes and genetic predispositions (Zhai et al., 2018). Dopamine regulation is also linked with language and cognitive dysfunction in Parkinson's disease (McNamara \& Durso, 2018). Studies have also pointed to several epigenetic and genetic causes for cognition (Day \& Sweatt, 2011; Deary et al., 2010; Parasuraman, 2009). Since higher cognitive skills are known to develop through a habit of reading (Wolf \& Barzillai, 2009), the neurobiology of reading must interact with the neurobiology of cognition to enrich the higher cognitive abilities.

Though reading enhances higher-order cognition and language to express complex thoughts in an effective language successfully, it is essential to recognize that cognition and language are dissociated in terms of their brain functionality. The brain areas corresponding to language and cognition, though intertwined in neural structure, are different in their functions (Berwick et al., 2013; Gazzaniga \& Smylie, 1984; Perlovsky \& Sakai, 2014; Sakai, 2005). Further, disorders that are related to language do not primarily affect cognition and vice versa. For instance, children affected by Developmental Verbal Dyspraxia (DVD) lack language but their IQ though

less, is within the normal range (Gopnik \& Crago, 1991; Vargha-Khadem et al., 1995). Similarly, a person who is affected by William's Syndrome may not produce meaningful sentences, but many aspects of language (vocabulary and phonological processing) are intact (Mervis \& Velleman, 2011). Thus, reading acts as a key link between the otherwise dissociated higher cognition and language of a person, given they are biologically gifted with favourable cognition and language predispositions.

\subsection{Reading and Emotion}

Brain processes of emotion are the drivers of reading habit. If a reader derives pleasure out of reading habit, they continue reading as a habit. This phenomenon can be attributed to increased pleasure-inducing neurotransmitters, such as dopamine and serotonin (Sharot et al., 2009). Conversely, if the reading gets stressful, the reader will be anxious towards reading since they are subjected to neurotransmission associated with stress. If stress is intense and extends to a prolonged period, it can affect genes through epigenetic mechanisms of stress (McEwen, 2016; McEwen et al., 2012). Similarly, the pleasure derived from reading also will have epigenetic impact, extending the benefits of reading for a long duration.

As a person reads, there are two broad categories of emotions that come into picture: the emotions that are related to the meaning of the utterances and the emotions that are associated with the reading activity. The second type of emotions, otherwise known as affective factors, involve attitude towards reading, motivation to continue reading, and anxiety associated with reading. 
These factors play a major role in extensive reading in the second language (L2) classrooms (CarrióPastor \& Mestre, 2014) and reading in the first language (Henter, 2014). The affective factors are favorable during the acquisition of the first language (Li) for children without reading disability. Mostly, children do not face any kind of anxiety stemming during the process of language acquisition. Since, L2 is acquired in a similar fashion as L1 (Perani \& Abutalebi, 2005), the absence of negative affective factors (also hypothesized as affective filter by Krashen) is also a necessary condition for effective second language acquisition (Krashen, 1982; Ni, 2012).

The emotion circuitry of the brain is closely associated with cognition, and they together support language acquisition (Sriganesh et al., 2018). Neural networks related to emotion and cognition interact dynamically and cannot be separated from each other (Gray, 1990; Jablonka et al., 2012; Pessoa, 2008; Scult \& Hariri, 2018). Such a dynamic interaction between emotion and cognition is reflected in language utterances also. In fact, it is closely associated with every word uttered in any language. For example, a study reveals that emotion-laden words corresponded with activities in brain regions associated with corresponding emotions (Hsu et al., 2015; Puetz et al., 2016). Another study points to motivation levels, self-regulation, and supportive interpersonal interactions play a significant role in language acquisition in general and second language acquisition in particular (Méndez López \& Fabela Cárdenas, 2014). In addition, positive emotions (such as enhanced motivation and reduced anxiety) associated with reading task, along with the cognitive support, aid in effective language acquisition, suggesting the mutual co-operation of brain areas corresponding to these abilities.

\section{How Reading Aids in Enhancing LCE}

The role of reading in linguistic, emotional, and cognitive development is inimitable. Language acquisition, higher cognition, and emotion are enhanced through reading and thus reading motivates readers to express their thoughts effectively. While previous sections focussed on biology of the relationship between reading and LCE, this section attempts to provide an account of how reading enables the improvements in LCE.

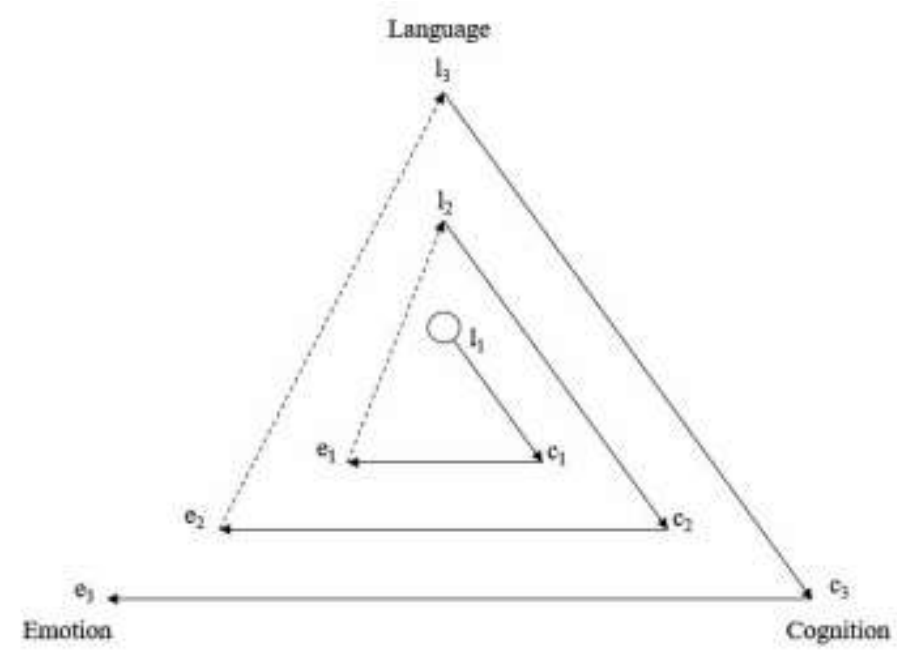

The circle at the centre represents beginning stage of reading

$l_{1}, l_{2}$, and $l_{3}$ are the successive language proficiency levels

$c_{1}, c_{2}$, and $c_{3}$ are the successive cognitive proficiency levels

$e_{1}, e_{2}$, and $e_{3}$ are the successive levels of emotion (motivation and attitudes towards reading) 
Figure 1: Conceptual model of how reading influences LCE

\subsection{Conceptual Model for Reading-induced Development of LCE}

Fig.1 represents a conceptual model of reading-enabled interactions among LCE circuitry of the brain in an ideal reading environment. The processes depicted in the model are applicable for readers whose reading and LCE are not affected by any unfavorable biological underpinning such as gene mutations or environmental hurdles such as stressful learning which may result in the deficiency of one or more abilities in consideration. To put differently, the efficiency of the progression to the next levels of proficiency may differ among individuals due to inter-individual differences in biology and the differences in environmental reading input.

The circle in Fig.1 signifies the beginning stage of reading, where the learner achieves phonological awareness and possesses an elementary level of vocabulary knowledge and sufficient syntactic knowledge to process simple sentences. The level $l_{1}$ represents the proficiency level that is slightly above the beginner-level reading so that it is both challenging enough (so that the learner does not find it too simple) and aids in language acquisition as well. This level of language proficiency is comparable to $i+1$, as explained in Krashen's second language acquisition theories (Krashen, 1982; 2004).

Once the text of level $l_{1}$ is successfully processed in the linguistic brain areas, the cognitive processes takeover and the text is interpreted, and the meaning is associated with the world knowledge of the reader to result in comprehension and higher-order thinking. This stage is represented in the figure as $\mathrm{c}_{1}$. Comprehension of the text is an important factor in deciding whether the text interests and motivates the reader. Successful comprehension passes the baton to emotion circuitry. The emotions associated with attitudes, motivation and/or anxiety resulting from $\mathrm{c}_{1}$ level is reflected in emotion circuitry of the brain. This level is denoted in the figure as $e_{1}$. It is to be noted that cognitive and emotive aspects of language ( $\mathrm{c} 1$ and el) are triggered simultaneously since the brain circuits for cognition and emotion work simultaneously and are highly intertwined. Cognition helps us understand the emotional content of the text and emotions influence cognition by giving "the energy that drives, organizes, amplifies and accentuates all thinking and reasoning" (Zambo \& Brem, 2004, p. 189). This interaction is so strong that research reveals neurogenetic underpinnings for emotion-cognition interactions (Scult \& Hariri, 2018). Therefore, reading should not be looked at in isolation without understanding its engagement with emotions and cognition.

The line from $e_{1}$ level to $l_{2}$ level is represented in a dotted line to denote that the decision to read further depends on two criteria: First, the emotion level $e_{1}$ which is related to cognition level $c_{1}$ is positive. Second, the previous level $l_{1}$ becomes too simple over a period, and the next level $l_{2}$ becomes the comprehensible input, $i+1$. For example, if the reader finds the text interesting and is motivated to read further, they will proceed to the reading further. However, reading at the same level of simple sentences may not be suitable for his current levels of cognition attained through $l_{1}$ stage reading. In that case, the reader autonomously chooses slightly complicated texts. This next level of language proficiency is denoted as $1_{2}$.

In a similar way, successful linguistic processing of $l_{2}$ would lead to achieving cognitively challenging $c_{2}$ level. Then the emotion associated with the cognitive level $c_{2}$ will predict if the reader is motivated enough to read further to reach the emotion level $e_{2}$. After a while, if the reader is further motivated to read further even texts that are slightly challenging yet comprehensible, they move to the better level of language proficiency, $l_{3}$ and this continues throughout the reader's life. 
While this process is a natural and organic way of learning, it is not the case in many language classrooms. For example, the progression to further levels is not the same for all individuals. A child with reading difficulty may take longer to transition to further stages of language proficiency. However, in typical classrooms, the introduction of progressive levels of texts are only bound by a common time period and not based on the natural time it may take for the child to achieve the level.

Secondly, the emotion factor is also not a consideration in reading classrooms. In a natural reading setup, learners choose the texts based on what interests them and what level of language and cognitive proficiency is required for reading the text. Thus the choice of the text primarily is based on emotion, and it becomes a habit when the brain finds it pleasurable. However, typical reading classrooms force learners to read what is deemed as a common text for all learners. A forceful reading of texts, that are perceived as stressful or boring, has been proved to be detrimental to language acquisition (Hashemi, 2011).

To avoid stressful learning situations, learners must be free to choose the reading text. A reader's innate drive will be to choose books that are both interesting, and are of their comprehensible level, $i+1$. The autonomous process of selecting reading material depends upon psychological factors that human beings generally need for their well-being. They innately look for factors such as competence, autonomy and relatedness for their mental well-being (Ryan \& Deci, 200o). These needs drive the motivation to habituate reading. Human beings are intrinsically motivated to seek novelty and challenges (Ryan \& Deci, 200o). So, a learner will be inherently motivated to read, if reading classrooms provide avenues for challenges, autonomy and relatedness. In short, the classroom environment must nourish the learners' innate desires to achieve.

\section{Interventions for Learning Difficulties/Disability}

Reading and language development cannot be viewed in terms of pedagogical/environmental interventions alone. Intervention for learning difficulties/disability can be holistic only when reading is viewed through biology (encompassing neurophysiology, neuropsychology, genetics and epigenetics) of reading and LCE. Such a perspective will help diagnose the precise cause of the learning disability. Advancements in neuroimaging (such as fMRI and fNIRS) and neurogenetics help diagnose the exact biological cause of the learning disability and understand the most efficient way the successful neural connections are established in the brain. Thus, using the knowledge of biological attributes of reading and LCE, clinical interventions could be synchronized with pedagogical interventions (Dehaene, 2010; Wandell \& Le, 2017; Wandell \& Yeatman, 2013).

In addition to neuroscience-based interventions, epigenetic- and neurotransmitter- based medical intervention is a possibility for treating learning disability. For example, vitamin B12 in fortified food products can act as methyl donors and treat neurobiological conditions. A study found that vitamin B12 fortified milk provided to children significantly raised their academic performance, motivation, and learning (Wang et al., 2017). Epigenetic modifications such as chromatin remodeling, DNA methylation and histone modification are found to ameliorate deficits in synaptic plasticity, cognition and stress (Abel \& Zukin, 2008). As we had discussed, synaptic plasticity, cognition and stress (emotion) influence reading brain circuitry. 


\section{Conclusion}

The neurobiology of reading and LCE has revealed interconnectivity in terms of brain structure and mutual support in terms of brain functions. Biological underpinnings (genetics and epigenetics), of both reading ability and LCE, act as preconditions for successful interaction among the brain functions. If the preconditions are favourable, reading habit favourably influences each of LCE. It helps learners achieve organic and incremental development in reading ability along with improved language acquisition, enhanced cognitive support and favourable emotions for reading. Therefore, genetics, epigenetics and neurobiology of reading and LCE, along with effective pedagogical interventions, must be taken into account to solve learning difficulties/disability and to provide targeted clinical and educational intervention.

\section{References}

Abel, T., \& Zukin, R. S. (2008). Epigenetic targets of HDAC inhibition in neurodegenerative and psychiatric disorders. Current Opinion in Pharmacology, 8(1), 57-64. https://doi.org/10.1016/j.coph.2007.12.002

Berwick, R. C., Friederici, A. D., Chomsky, N., \& Bolhuis, J. J. (2013). Evolution, brain, and the nature of language. Trends in Cognitive Sciences, 17(2), 89-98. https://doi.org/10.1016/j.tics.2012.12.002

Black, J. E., \& Barnes, J. L. (2015). The effects of reading material on social and non-social cognition. Poetics, 52, 32-43. https://doi.org/10.1016/j.poetic.2015.07.001

Carrió-Pastor, M. L., \& Mestre, E. M. M. (2014). Motivation in Second Language Acquisition. Procedia Social and Behavioral Sciences, 116(2002), 240-244. https://doi.org/10.1016/j.sbspro.2014.01.201

Caspi, A., Hariri, A. R., Andrew, H., Uher, R., \& Moffitt, T. E. (2010). Genetic sensitivity to the environment: The case of the serotonin transporter gene and its implications for studying complex diseases and traits. American Journal of Psychiatry, 167(5), 509-527. https://doi.org/10.1176/appi.ajp.2010.09101452

Clark, C., \& Rumbold, K. (2006). Reading for pleasure: A research overview. In National Literacy Trust. Retrieved from http://www.scholastic.com/teachers/article/collateral_resources/pdf/i/Reading_for_pleasure.pdf

Cope, N., Harold, D., Hill, G., Moskvina, V., Stevenson, J., Holmans, P., ... Williams, J. (2005). Strong evidence that KIAAo319 on chromosome $6 \mathrm{p}$ is a susceptibility gene for developmental dyslexia. American Journal of Human Genetics, 76(4), 581-591. https://doi.org/10.1086/429131

Cortés-mendoza, J., de León-guerrero, S. D., Pedraza-alva, G., \& Pérez-Martínez, L. (2013). Shaping synaptic plasticity: The role of activity-mediated epigenetic regulation on gene transcription. International Journal of Developmental Neuroscience, 31(6), 359-369. https://doi.org/10.1016/j.ijdevneu.2013.04.003

Cunningham, A. E., \& Stanovich, K. E. (1998). What reading does for mind. American Educator, 22(1 \& 2), 815 .

Day, J. J., \& Sweatt, J. D. (2011). Epigenetic Mechanisms in Cognition. Neuron, 7o(5), 813-829. https://doi.org/10.1016/j.neuron.2011.05.019

Deary, I. J., Penke, L., \& Johnson, W. (2010). The neuroscience of human intelligence differences. Nature Reviews Neuroscience, 11, 201-211. https://doi.org/10.1038/nrn2793

Dehaene, S. (2010). Reading in the Brain: The Science and Evoluion of a Human Invention. New York, NY: Viking.

Dehaene, S., Cohen, L., Morais, J., \& Kolinsky, R. (2015). Illiterate to literate: behavioural and cerebral 
changes induced by reading acquisition. Nature Reviews. Neuroscience, 16(4), 234-244. https://doi.org/10.1038/nrn3924

Elvevåg, B., \& Weinberger, D. R. (2009). Introduction: Genes, cognition and neuropsychiatry. Cognitive Neuropsychiatry, 14(4-5), 261-276. https://doi.org/10.108o/13546800903126016

Felling, R. J., \& Song, H. (2015). Epigenetic mechanisms of neuroplasticity and the implications for stroke recovery. Experimental Neurology, 268, 37-45. https://doi.org/10.1016/j.expneurol.2014.09.017

Gazzaniga, M. S., \& Smylie, C. S. (1984). Dissociation of language and cognition: A psychological profile of two disconnected right hemispheres. Brain, 107, 145-153. https://doi.org/10.1093/brain/107.1.145

Ghanbari, M., \& Marzban, A. (2014). Effect of extensive reading on incidental vocabulary retention. Procedia - Social and Behavioral Sciences, 116, 3854-3858. https://doi.org/10.1016/j.sbspro.2014.01.854

Gialluisi, A., Guadalupe, T., Francks, C., \& Fisher, S. E. (2017). Neuroimaging genetic analyses of novel candidate genes associated with reading and language. Brain and Language, 172, 9-15.

https://doi.org/10.1016/j.bandl.2016.07.002

Gialluisi, A., Newbury, D. F., Wilcutt, E. G., Consortium, T. S. L. I., \& Luciano, M. (2014). Genome-wide screening for DNA variants associated with reading and language traits. Genes, Brain and Behavior, 13(7), 686-701. https://doi.org/10.1111/gbb.12158

Gopnik, M., \& Crago, M. B. (1991). Familial aggregation of a developmental language disorder. Cognition, 39, 1-50. https://doi.org/10.1016/oo10-0277(91)90058-C

Gray, J. A. (1990). Brain Systems that Mediate both Emotion and Cognition. Cognition and Emotion, 4(3), 269-288. https://doi.org/10.1080/02699939008410799

Hannula-Jouppi, K., Kaminen-Ahola, N., Taipale, M., Eklund, R., Nopola-Hemmi, J., Kääriäinen, H., \& Kere, $\mathrm{J}$. (2005). The axon guidance receptor gene $\mathrm{ROBO} 1$ is a candidate gene for developmental dyslexia. PLoS Genetics, 1(4), 0467-0474. https://doi.org/10.1371/journal.pgen.0010050

Hashemi, M. (2011). Language stress and anxiety among the English language learners. Procedia - Social and Behavioral Sciences, 30, 1811-1816. https://doi.org/10.1016/j.sbspro.2011.10.349

Henter, R. (2014). Affective Factors Involved in Learning a Foreign Language. Procedia - Social and Behavioral Sciences, 127, 373-378. https://doi.org/10.1016/j.sbspro.2014.03.274

Hsu, C. T., Jacobs, A. M., \& Conrad, M. (2015). Can Harry Potter still put a spell on us in a second language? An fMRI study on reading emotion-laden literature in late bilinguals. Cortex, 63, 282-295. https://doi.org/10.1016/j.cortex.2014.09.002

Jablonka, E., Ginsburg, S., \& Dor, D. (2012). The co-evolution of language and emotions. Philosophical Transactions: Biological Sciences, 367(1599), 2152-2159. https://doi.org/10.1098/rstb.2012.0117

Jennifer, J. M., \& Ponniah, J. R. (2018). Acquisition of Writing by Reading and Its Impact on Cognition. In R. J. Ponniah \& S. Venkatesan (Eds.), The Idea and Practice of Reading (pp. 41-56). https://doi.org/10.1007/978-981-10-8572-7

Jennifer, J. M., \& Ponniah, R. J. (2017). Investigating the Levels, Types and Causes of Second Language Writing Anxiety among Indian Freshmen. Journal of Asia TEFL, 14(3), 557-563. https://doi.org/10.18823/asiatefl.2017.14.3.13.557

Kennedy, A. J., Rahn, E. J., Paulukaitis, B. S., Savell, K. E., Kordasiewicz, H. B., Wang, J., ... Sweatt, J. D. (2016). Tcf 4 regulates synaptic plasticity, DNA methylation, and memory function. Cell Reports, 16, 120. https://doi.org/10.1016/j.celrep.2016.08.004

Kidd, D. C., \& Castano, E. (2013). Reading Literary Fiction Improves Theory of Mind. Science, 342(6156), 377380. https://doi.org/10.1126/science.1239918

Krashen, S. D. (1982). Priniciples and practice in second language acquisition (1st ed.). Penguin Press Inc. 
Krashen, S. D. (2004). The power of reading: Insights from the research. In Libraries Unlimited. Westport, CT: Libraries Unlimited.

Kraus, C., Castrén, E., Kasper, S., \& Lanzenberger, R. (2017). Serotonin and Neuroplasticity - Links between molecular, functional and structural pathophysiology in depression. Neuroscience $\mathcal{E}$ Biobehavioral Reviews, 77, 317-326. https://doi.org/10.1016/j.neubiorev.2017.03.007

Lee, J., Schallert, D. L., \& Kim, E. (2015). Effects of extensive reading and translation activities on grammar knowledge and attitudes for EFL adolescents. System, 52, 38-50. https://doi.org/10.1016/j.system.2015.04.016

Malle, B. F. (2005). Folk Theory of Mind: Conceptual Foundations of Human Social Cognition. In R. Hassin, S. J. Uleman, \& J. A. Bargh (Eds.), The new unconscious (pp. 225-255). https://doi.org/10.1093/acprof:0so/9780195307696.003.0010

McEwen, B. S. (2016). In pursuit of resilience: stress, epigenetics, and brain plasticity. Annals of the New York Academy of Sciences, 1373(1), 56-64. https://doi.org/10.1111/nyas.13020

McEwen, B. S., Eiland, L., Hunter, R. G., \& Miller, M. M. (2012). Stress and anxiety: Structural plasticity and epigenetic regulation as a consequence of stress. Neuropharmacology, 62(1), 3-12. https://doi.org/10.1016/j.neuropharm.2011.07.014

McNamara, P., \& Durso, R. (2018). The dopamine system, Parkinson's disease and language function. Current Opinion in Behavioral Sciences, 21, 1-5. https://doi.org/10.1016/j.cobeha.2017.10.010

Méndez López, M. G., \& Fabela Cárdenas, M. A. (2014). Emotions and their effects in a language learning Mexican context. System, 42(1), 298-307. https://doi.org/10.1016/j.system.2013.12.006

Meng, H., Smith, S. D., Hager, K., Held, M., Liu, J., Olson, R. K., ... Gruen, J. R. (2005). DCDC2 is associated with reading disability and modulates neuronal development in the brain. Proceedings of the National Academy of Sciences, 102(47), 17053-17058. https://doi.org/10.1073/pnas.0508591102

Mervis, C. B., \& Velleman, S. L. (2011). Children with Williams Syndrome: Language, cognitive, and behavioral characteristics and their implications for intervention. Perspectives on Language Learning and Education, 18(3), 98-107. https://doi.org/10.1044/lle18.3.98

Mol, S. E., Bus, A. G., \& de Jong, M. T. (2009). Interactive Book Reading in Early Education: A Tool to Stimulate Print Knowledge as Well as Oral Language. Review of Educational Research, 79(2), 979-1007. https://doi.org/10.3102/0034654309332561

Morris, B. J. (2004). Neuronal Plasticity. In W. R. Davies \& B. J. Morris (Eds.), Molecular Biology of the Neuron (2nd ed., pp. 353-382). Retrieved from Oxford

Ni, H. (2012). The Effects of Affective Factors in SLA and Pedagogical Implications. Theory and Practice in Language Studies, 2(7), 1508-1513. https://doi.org/10.4304/tpls.2.7.1508-1513

Olson, R. K. (2006). Genes, environment, and dyslexia The 2005 Norman Geschwind memorial lecture. Annals of Dyslexia, 56(2), 205-238. https://doi.org/10.1007/s11881-006-0o10-6

Onnis, L., Truzzi, A., \& Ma, X. (2018). Language development and disorders: Possible genes and environment interactions. Research in Developmental Disabilities, 82(Nov), 132-146. https://doi.org/10.1016/j.ridd.2018.06.015

Parasuraman, R. (2009). Assaying individual differences in cognition with molecular genetics: Theory and application. Theoretical Issues in Ergonomics Science, 10(5), 399-416. https://doi.org/10.1080/14639220903106403

Perani, D., \& Abutalebi, J. (2005). The neural basis of first and second language processing. Current Opinion in Neurobiology, 15(2), 202-206. https://doi.org/10.1016/j.conb.2005.03.007

Perlovsky, L., \& Sakai, K. L. (2014). Language acquisition and brain development. Frontiers in Behavioral 
Neuroscience, 8, 1-2. https://doi.org/10.1126/science.1113530

Pessoa, L. (2008). On the relationship between emotion and cognition. Nature Reviews Neuroscience, 9(2), 148-158. https://doi.org/10.1038/nrn2317

Petersson, K. M., Reis, A., Askelöf, S., Castro-Caldas, A., \& Ingvar, M. (200o). Language processing modulated by literacy: A network analysis of verbal repetition in literate and illiterate subjects. Massachusetts Institute of Technology Journal of Cognitive Neuroscience, 12(3), 364-382. https://doi.org/10.1162/o89892900562147

Puetz, V. B., Viding, E., Palmer, A., Kelly, P. A., Lickley, R., Koutoufa, I., ... McCrory, E. J. (2016). Altered neural response to rejection-related words in children exposed to maltreatment. Journal of Child Psychology and Psychiatry and Allied Disciplines, 57(10), 1165-1173. https://doi.org/10.1111/jcpp.12595

Raskind, W. H., Peter, B., Richards, T., Eckert, M. M., \& Berninger, V. W. (2013). The genetics of reading disabilities: From phenotypes to candidate genes. Frontiers in Psychology, 3(Jan), 1-20. https://doi.org/10.3389/fpsyg.2012.006o1

Richiardi, J., Altmann, A., \& Jonas, R. (2015). Correlated gene expression supports synchronous activity in brain networks. Science, 348(6240), 11-14. https://doi.org/10.1126/science.1255905

Ryan, R., \& Deci, E. (2000). Self-determination theory and the facilitation of intrinsic motivation, social development, and well-being. The American Psychologist, 55(1), 68-78. https://doi.org/10.1037/ooo3o66X.55.1.68

Sakai, K. L. (2005). Language Acquisition and Brain Development. Science, 310(5749), 815-819. https://doi.org/10.1126/science.1113530

Scerri, T. S., Darki, F., Newbury, D. F., Whitehouse, A. J. O., Peyrard-Janvid, M., Matsson, H., ... Paracchini, S. (2012). The dyslexia candidate locus on 2 p12 is associated with general cognitive ability and white matter structure. PLoS ONE, 7(11), e50321. https://doi.org/10.1371/journal.pone.0050321

Scerri, T. S., Morris, A. P., Buckingham, L., Newbury, D. F., Miller, L. L., Bishop, D. V. M., \& Paracchini, S. (2011). DCDC2, KIAAo319 and CMIP are associated with reading-related traits. Biological Psychiatry, 70(3), 237-245. https://doi.org/10.1016/j.biopsych.2011.02.005

Scult, M. A., \& Hariri, A. R. (2018). A brief introduction to the neurogenetics of cognition-emotion interactions. Current Opinion in Behavioral Sciences, 19, 50-54. https://doi.org/10.1016/j.cobeha.2017.09.014

Sharot, T., Shiner, T., Brown, A. C., Fan, J., \& Dolan, R. J. (2009). Dopamine enhances expectation of pleasure in humans. Current Biology, 19(24), 2077-2080. https://doi.org/10.1016/j.cub.2009.10.025

Swagerman, S. C., van Bergen, E., Dolan, C., de Geus, E. J. C. C., Koenis, M. M. G. G., Hulshoff Pol, H. E., \& Boomsma, D. I. (2017). Genetic transmission of reading ability. Brain and Language, 172, 3-8. https://doi.org/10.1016/j.bandl.2015.07.008

Taipale, M., Kaminen, N., Nopola-Hemmi, J., Haltia, T., Myllyluoma, B., Lyytinen, H., ... Kere, J. (2003). A candidate gene for developmental dyslexia encodes a nuclear tetratricopeptide repeat domain protein dynamically regulated in brain. Proceedings of the National Academy of Sciences of the United States of America, 100 (20), 11553-11558. https://doi.org/10.1073/pnas.1833911100

Tran, C., Wigg, K. G., Zhang, K., Cate-Carter, T. D., Kerr, E., Field, L. L., ... Barr, C. L. (2014). Association of the ROBO1 gene with reading disabilities in a family-based analysis. Genes, Brain and Behavior, 13(4), 430-438. https://doi.org/10.1111/gbb.12126

Vargha-Khadem, F., Watkins, K., Alcock, K., Fletcher, P., \& Passingham, R. (1995). Praxic and nonverbal cognitive deficits in a large family with with a genetically transmitted speech and language disorder. Proceedings of the National Academy of Sciences USA, 92(January), 930-933.

https://doi.org/10.1073/pnas.92.3.930 
Wandell, B. A., \& Le, R. K. (2017). Diagnosing the Neural Circuitry of Reading. Neuron, 96(2), 298-311. https://doi.org/10.1016/j.neuron.2017.08.007

Wandell, B. A., \& Yeatman, J. D. (2013). Biological development of reading circuits. Current Opinion in Neurobiology, 23(2), 261-268. https://doi.org/10.1016/j.conb.2012.12.005

Wang, X., Hui, Z., Dai, X., Terry, P. D., Zhang, Y., Ma, M., ... Zhang, B. (2017). Micronutrient-fortified milk and academic performance among Chinese middle school students: A cluster-randomized controlled trial. Nutrients, 9(3), 226. https://doi.org/10.3390/nu9030226

Wasik, B. A., Hindman, A. H., \& Snell, E. K. (2016). Book reading and vocabulary development: A systematic review. Early Childhood Research Quarterly, 37, 39-57. https://doi.org/10.1016/j.ecresq.2016.04.003

Wolf, M., \& Barzillai, M. (2009). The Importance of Deep Reading. Educational Leadership, 66(6), 32-37. Retrieved from http://www.ascd.org/

Zambo, D., \& Brem, S. K. (2004). Emotion and cognition in students who struggle to read: New insights and ideas. Reading Psychology, 25(3), 189-204. https://doi.org/10.1080/02702710490489881

Zhai, D., Li, S., Dong, G., Zhou, D., Yang, Y., Wang, X., ... Lin, Z. (2018). The correlation between DNA methylation and transcriptional expression of human dopamine transporter in cell lines. Neuroscience Letters, 662(February 2017), 91-97. https://doi.org/10.1016/j.neulet.2017.10.013 